\title{
Prevalence and diversity of ectoparasites in scavenging chickens (Gallus domesticus) and their association to body weight
}

\author{
EDY RIWIDIHARSO`, DARSONO, ENDANG ARIYANI SETYOWATI, HERY PRATIKNYO, \\ EMING SUDIANA, SLAMET SANTOSO, EDY YANI, IMAM WIDHIONO \\ Faculty of Biology, Universitas Jenderal Soedirman. J1. Dr. Soeparno No. 63, Karangwangkal, Purwokerto Utara, Banyumas 53122, Central Java, \\ Indonesia. Tel./fax.: +62-281-638794, `email: edyriwi@yahoo.co.id
}

Manuscript received: 19 April 2020. Revision accepted: 18 June 2020

\begin{abstract}
Riwidiharso E, Darsono, Setyowati EA, Pratiknyo H, Sudiana E, Santoso S, Yani E, Widhiono I. 2020. Prevalence and diversity of ectoparasites in scavenging chickens (Gallus domesticus) and their association to body weight. Biodiversitas 21: 31633169. Domestic chickens (Gallus domesticus) which are traditionally fed by scavenging on farms predispose them to ectoparasites infestation. In this study, a preliminary survey was conducted on the common ectoparasites on G. domesticus in the rural areas of Banyumas District, Central Java, Indonesia. The purpose of this study was to determine the diversity of ectoparasites, their prevalence, and their relationship to the chickens' body weight. This research was conducted by the survey method from December 2019 to April 2020 in five villages around the city of Purwokerto, Banyumas District viz., Kedungwuluh, Kedungwringin, Kutasari, Karangsalam, and Karanggintung. Analysis of ectoparasites diversity was conducted by using the Shannon-Wiener index $\left(\mathrm{H}^{\prime}\right)$ and Evenness index $(\mathrm{E})$. Analysis of variance was used to calculate the difference in prevalence among sample locations. Regression correlation analysis was used to determine the relationship between prevalence and chicken body weight. The results showed that there were six ectoparasite species i.e., Dermanysus gallinae, Megninia ginglymura, Menacanthus cornutus, Menopon gallinae, Lipeurus caponis, and Haemaphysalis sp. parasitizing $G$. domesticus in five villages. The number of ectoparasite individuals among locations was significantly different (F $5.59<$ $32.45 ; \mathrm{p}<0.05)$. The highest number of ectoparasite was found in Karangsalam (272 individuals), while the highest prevalence of ectoparasite was $M e$. cornutus $(45 \%)$. Ectoparasite prevalence was associated with chicken weight loss $(\mathrm{r}=0.98)$. The prevalence of ectoparasite of domestic chickens farm in the Banyumas Regency is classified as low but has the potential to influence body weight.
\end{abstract}

Keywords: Ayam kampong, body weight, ectoparasite, prevalence, traditional farm

\section{INTRODUCTION}

Rural chicken farms are generally managed very simply. Consequently, they are very vulnerable to both endo and ectoparasites attack (Suhaila et al. 2015). Domestic chicken production in rural areas faces many obstacles such as insufficient feed, poor management, and poor biosecurity (Nik-Hasan et al. 2015). The habit of releasing native chickens throughout the day to get food on their own makes them very susceptible to ectoparasite attacks. This is because these chickens accidentally contract infective eggs, larvae, and intermediate hosts from ectoparasites. According to Rahman and Haziqoh (2015), ectoparasite attack is one of the main problems in the farming of indigenous chickens in the countryside.

The common ectoparasites in native chickens are fleas and mites. The fleas are generally from the order Phthiraptera, sub order Mallophaga (Suaila et al. 2015). Ilyes et al. (2013) found that ectoparasite attacks can cause health problems in chickens by damaging tissue and causing blood loss and toxicosis dermatitis. In addition to these symptoms, Aleya and Sabrina (2011) also found allergies. Several types of ectoparasites can also cause or act as a vector of various pathogens, which, in severe attacks, will weaken the hens and cause death (Swai et al. 2010; Nik-Hasan et al. 2015). According to Gunya et al. (2020), the most common external parasite in the scavenging chicken were mites, followed by lice. Lice and mites can cause chick mortality, attributed to starvation and immune suppression from the infestation (Nnadi and George 2010)

Ectoparasites are very common in native chickens in traditional chicken farms in various countries such as USA (California state) (Murillo and Mullens 2016), India (Sreedevi et al. 2016), Bulgaria (Prelezov and Koinarski 2006), Egypt (El-Aw et al. 2008), and Benin (Love et al. 2017). Nik-Hasan et al. (2015) found ectoparasites and their prevalence in Sandakan, Malaysian Borneo to be: Dermanyssus gallinae (78\%), Lipeurus caponis (80\%) and Menopon gallinae (100\%). Love et al. (2017), in their research on chewing lice in selected poultry in Benin, recorded the highest prevalence of ectoparasite was Menacanthus stramineus (56\%), followed by Menopon gallinae (34\%) and Lipeurus caponis $(10 \%)$.

Ectoparasites in chickens, aside from the insect class, are also found from the mite class Arachnida and subclass Acari and ticks (Ixodidae). Two species of mites commonly found in chickens around the world are D. gallinae and Megninia ginglymura. D. gallinae is a blood-sucking mite that causes decreased egg-laying ability and anemia in chickens and can be a vector of disease in humans and other animals (Sparagano et al. 2009). The presence of these mites will affect the hens' ability to lay eggs and can cause disease from viruses and bacteria (Marangi et al. 
2009). M. ginglymura is almost found in chickens and associates with feathers. Its saliva can cause lesions, allergic reactions with pruritus, serous scabs, stress, and itching, leading to the development of petechial hemorrhage, crust formation, secondary bacterial infections, and pyoderma (Faleireo et al. 2015). Huge mortality, slow growth rate, and malnutrition are common problems in scavenging chicken (FAO 2014). Parasitic infection is one of the non-infectious health hazards in backyard chicken, whose severity and diversity are primarily influenced by geography and climatic interaction. The parasitic problem has been identified as one of the causes of low productivity in free-range chicken (Olivirea et al. 2017).

In Banyumas District, chicken farms are maintained traditionally and only at the household scale, with a relatively small chicken population reared in a small scale system. However, this activity is very important for the rural economy and is used as a medium-term saving. Although ectoparasites in native chickens are an important factor in poultry, research on the diversity and prevalence of ectoparasites and their effects on native chicken body weight is still very rare in Indonesia. Therefore, the purpose of this study was to determine the diversity and prevalence of ectoparasites, their attack rates, and their relationship to the bodyweight of the native chicken. The long-term goal of this research is to establish a basis for controlling ectoparasite attacks in left-over native chickens.

\section{MATERIALS AND METHODS}

\section{Study area}

The study was conducted on 100 scavenging chickens randomly obtained from five villages around Purwokerto, Banyumas District, Central Java, Indonesia, viz., Kedungwuluh (sub-district West Purwokerto), Kedungwringin (sub-district Patikraja), Kutasari (sub-district Baturaden), Karangsalam (sub-district Kedungbanteng) and Karanggintung (sub-district Sumbang) (Figure 1). The chickens had been left scavenging around the house.

\section{Procedures}

Chicken sampling procedures

Chicken samples were randomly obtained directly from the owner in the selected village. They were completely left day and night. The average age of the chicken is eight months based on information from the owner. From each village, twenty chickens were taken, consisting of ten hens and ten cocks. Each chicken was weighed. At the time of chicken sampling, environmental conditions of each location were observed, which included the cleanliness of the chicken's living area, chicken population per family, maintenance methods, feeding, and the size of the scavenging area (Table 1).
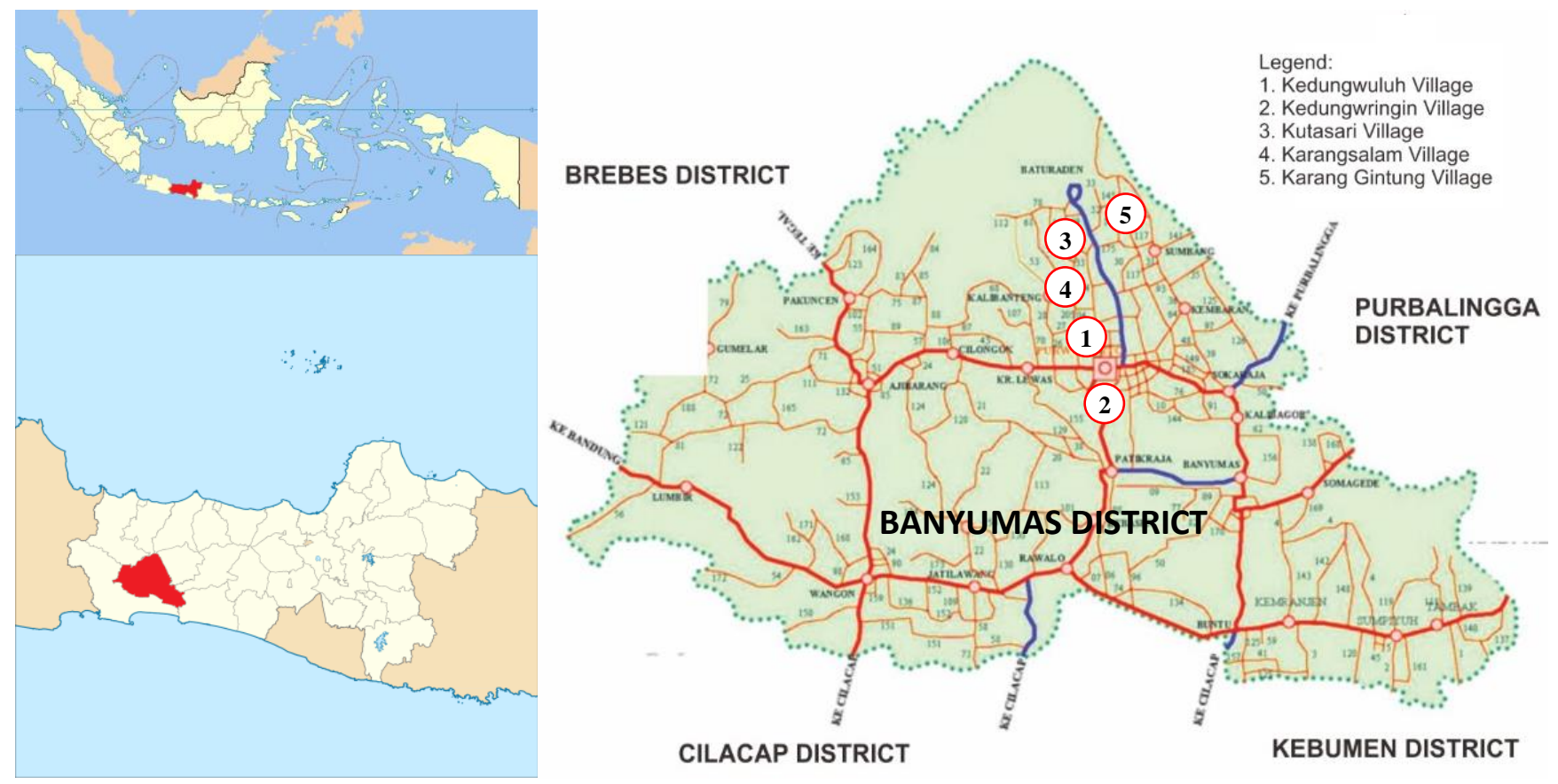

Figure 1. Sampling location at Banyumas District, Central Java, Indonesia

Table 1. Environmental parameters of five domestic chicken sampling sites

\begin{tabular}{lccccc}
\hline \multicolumn{1}{c}{ Parameter } & Kedungwuluh & Kedungwringin & Kutasari & Karangaslam & Karanggintung \\
\hline Temperature $\left({ }^{\circ} \mathrm{C}\right)$ & $30-32$ & $30-32$ & $30-32$ & $30-32$ & $30-32$ \\
Humidity $(\%)$ & $90-95$ & $90-95$ & $90-95$ & $90-95$ & $90-95$ \\
Cleanliness & Clean & Clean & Clean & Clean & Dirty \\
Populations (individual)/ family & $10-15$ & $5-10$ & $10-15$ & $10-15$ & $15-20$ \\
Living area (m) & $<50$ & $<50$ & $<50$ & $<50$ & $>50$ \\
Maintenance methods & free & cage & cage & cage & cage \\
\hline
\end{tabular}




\section{Ectoparasite sampling procedure}

Isolation of ectoparasites in the chickens was carried out by examining the following body parts; head-neck, back, wings, chest-legs, and tail. Further, the collected ectoparasites were put into a sample bottle containing $70 \%$ ethanol for observation in the Entomology and Parasitology Laboratory, Faculty of Biology, Jenderal Soedirman University. Ectoparasites were separated based on groups namely insects, mites, and ticks under a binocular microscope Olympus CH 20. For identification purposes, the specimens were prepared on an object glass and placed in Hoyer's solution for clearing in one week, and then they were identified according to Murillo and Mullens (2016).

\section{Data analysis}

Analysis of ectoparasites diversity data was done using the Shannon-Wiener index $\left(\mathrm{H}^{\prime}\right)$ and Evenness index $(\mathrm{E})$. All data were analyzed using BD Pro software (McAleece et al. 1997). Shannon-Wiener diversity and Evenness indexes were calculated with the formula (Magurran 2000):

$$
\mathrm{H}^{\prime}=\sum_{i=1}^{s} p i \ln p i
$$

Where; H': Shannon-Wiener diversity index, pi: total individual(s) found within species $i$.

$$
E=\frac{H^{\prime}}{\ln S}
$$

Where; E: Evenness index, H': Shannon-Wiener diversity index, S: total species of ectoparasite.

Simpson's dominance index was used to measure dominance following this formula:

$$
\mathrm{D}=\sum(p i)^{2}=\sum\left(\frac{n i}{N}\right)^{2}
$$

Where; D: Simpson's dominance index, ni: total individuals within a species, $\mathrm{N}$ : total individuals within all species.
Analysis of variance (ANOVA) was used to calculate the difference in prevalence between sample locations, and between males and females. Regression correlation analysis was used to determine the relationship between prevalence and chicken body weight. All analysis was run with the help of SPSS 21 software.

\section{RESULTS AND DISCUSSION}

\section{Ectoparasite diversity}

A total of 1047 ectoparasites consisting of three species of lice, two species of mite, and one species of ticks were found in this study. The species of lice encountered were Menopon gallinae (Phthiraptera, Menoponidae), Menacanthus stramineus (Phthiraptera, Menoponidae), and Lipeurus caponis (Phthiraptera, Philopteridae). The mites consisted of Megninia ginglymura (Astigmata, Analgidae) and Dermanyssus gallinae (Astigmata, Dermanyssidae) and the ticks were Haemaphysalis sp. (Ixodida: Ixodidae) (Table 2, Figure 1).

The number of species found is relatively small compared with other studies, probably due to the number of sampling size. High ectoparasite attacks are caused by the level of yard hygiene, air humidity, ambient temperature, and rainfall (Rahman and Haziqoh 2015). This result is in accordance with Nik-Hasan et al. (2015) in their study of parasitic burden and its relation with the bodyweight of free-range chicken in oil palm dominated Sandakan District of Malaysian Borneo where also only four species of ectoparasite were found.

Rahman and Haziqoh (2015) found ten species of ectoparasite in their study on native chicken in urban areas. Furthermore, a high diversity of ectoparasites was found in native chickens in the African region with recorded species including Menopon gallinae, Menacanthus stramineus, Menacanthus cornutus, Menacanthus pallidulus, Lipeurus caponis, Goniocotes gallinae, Goniodes dissimilis, Goniodes gigas (El-Aw et al. 2013). Zeryehun and Yohannes (2015) recorded five species of mites in the chickens reared under traditional backyard production

\begin{tabular}{|c|c|c|c|c|c|c|c|c|c|c|c|}
\hline \multirow{3}{*}{ Species } & \multicolumn{10}{|c|}{ Location } & \multirow{3}{*}{$\Sigma$} \\
\hline & \multicolumn{2}{|c|}{ I } & \multicolumn{2}{|c|}{ II } & \multicolumn{2}{|c|}{ III } & \multicolumn{2}{|c|}{ IV } & \multicolumn{2}{|c|}{$\mathbf{V}$} & \\
\hline & Cock & Hen & Cock & Hen & Cock & Hen & Cock & Hen & Cock & Hen & \\
\hline \multicolumn{12}{|l|}{ Lice } \\
\hline Menopon gallinae & 31 & 57 & 28 & 20 & 24 & 21 & 34 & 46 & 24 & 25 & 310 \\
\hline Lipeurus caponis & 16 & 27 & 18 & 13 & 14 & 16 & 21 & 25 & 11 & 23 & 184 \\
\hline Menacanthus cornutus & 24 & 37 & 34 & 22 & 19 & 28 & 32 & 37 & 21 & 36 & 290 \\
\hline \multicolumn{12}{|l|}{ Tick } \\
\hline \multirow{2}{*}{\multicolumn{12}{|c|}{ Mite }} \\
\hline & & & & & & & & & & & \\
\hline Dermanyssus gallinae & 10 & 15 & 12 & 7 & 5 & 1 & 10 & 13 & 7 & 11 & 91 \\
\hline Megninia ginglymura & 5 & 5 & 11 & 11 & 5 & 6 & 8 & 16 & 9 & 12 & 88 \\
\hline Total & 102 & 143 & 120 & 82 & 74 & 75 & 119 & 153 & 90 & 116 & 1074 \\
\hline
\end{tabular}
system in southern Ethiopia.

Table 2. Abundance of ectoparasite in kampong chicken

Note: I: Kedungwuluh, II: Kedungwringin, III: Kutasari, IV: Karangsalam, V: Karanggintung 
Among all the sampling sites in this study, the most abundant ectoparasite was Men. gallinae (310 individuals, $29.60 \%)$, followed by Me. cornuthus (290 individuals, $27 \%$ ), while the least was $M$. ginglymura with 88 individuals $(8 \%)$ (Table 1). This result showed that there were no significant differences among the sampling sites $\left(\mathrm{F}_{4.24} ; \mathrm{p}>0.05\right)$. The dominance of shaft louse (Men. gallinae $)$ is very common because this ectoparasite is widespread. $M$. gallinae attacks the base of the feathers and cause loss of chicken feathers. The adults of Men. gallinae measure about $2 \mathrm{~mm}$ in length, and females deposit eggs singly at the base of the shaft on thigh and breast feathers. Poultry lice typically transfer to new chicken by direct host contact. The abundance number of Men. gallinae cause it disperses easily among chicken.

Shannon diversity index $\left(\mathrm{H}^{\prime}\right)$ among the sampling sites was almost the same, ranging from $\mathrm{H}^{\prime}$ : 1.551 (site III) to $\mathrm{H}^{\prime}$ : 1.712 (site II). This means that all chicken sampled were invested by the same number species of ectoparasite (six ectoparasites) (Table 2). The density of the cage greatly influences the number of ectoparasites in chickens due to the high level of contact between individual chickens, as most transmissions of ectoparasites between individuals are by direct contact (Suahila et al. 2015). Besides insects, this study also found two species of mites, i.e., D. gallinae (91 individuals, $8.4 \%$ ) and $M$. ginglymura (88 individuals, $8.1 \%)$. The presence of these mites is common, because they are widespread in chickens throughout the world. $D$. gallinae is hematophagous and responsible for egg downgrading and anemia in birds (Sparagano et al. 2009). This ectoparasite is the most important affecting laying hens worldwide. The presence of this mite has been associated with a viral zoonosis and several bacterial infections (Marangi et al. 2009). One species of ticks
(Acari, Ixodidae) found in this study was Haemaphysallis sp., which is a bloodsucking tick and is widely distributed in Southeast Asia. This is a very important parasite in chicken farms because it can cause infection and become a vector of other diseases (Ernieenor et al. 2017). Haemaphysallis sp. was also found in the study of Rahman and Haziqoh (2015) in Malaysia with a low population.

The results showed that ectoparasite was found in the four parts observed, namely head-neck, back, wings, chestlegs, and tail. However, ectoparasite species have preferences for different chicken body parts. L. caponis was found in all of the observed chicken body parts, $M$. cornutus was found in four parts of the chicken body except wings, Men. gallinae was found only in the headneck, back, and chest-legs. M. ginglymura was found only on the wings and tail (Table 4).

Among the body parts of chickens, it was observed that the back and chest-legs were the most common abodes for ectoparasites with five species present, followed by headneck section with four species, and the wing had with three species. The lice identified were Men. gallinae, Me. cornutus, L. caponis, the mites were Goniocotes gallinae, M. ginglymura, and the scrab was Haemaphysallis sp.

\section{Prevalence}

At the five sampling locations, the highest prevalence was of Men. gallinae (45\%), followed by L. caponis (40\%), Me. cornutus (38\%), and M. ginglymura mites (25\%). This is caused by the nature of Men. gallinae (chicken body louse) as a voracious feeder so it can spread very fast. In addition, the development of Men. gallinae population is greatly influenced by changes in environmental factors, especially the air temperature (Ilyes et al. 2013).

Table 3. Diversity parameters of five different sampling site

\begin{tabular}{|c|c|c|c|c|c|}
\hline Diversity Parameters & Kedungwuluh & Kedungwringin & Kutasari & Karangaslam & Karanggintung \\
\hline Taxa_S & 6 & 6 & 6 & 6 & 6 \\
\hline Individuals & 245 & 202 & 149 & 272 & 206 \\
\hline Dominance_D & 0.2393 & 0.1941 & 0.2428 & 0.2066 & 0.1956 \\
\hline Shannon_H- & 1.575 & 1.712 & 1.551 & 1.675 & 1.707 \\
\hline Simpson_1-D & 0.7607 & 0.8059 & 0.7572 & 0.7934 & 0.8044 \\
\hline Evenness_e $\mathrm{e}^{\wedge} \mathrm{H} / \mathrm{S}$ & 0.8048 & 0.9238 & 0.7863 & 0.8895 & 0.9183 \\
\hline Equitability_J & 0.8788 & 0.9558 & 0.8658 & 0.9347 & 0.9524 \\
\hline
\end{tabular}

Table 4. Distribution of ectoparasite in the body regions of the domestic chicken

\begin{tabular}{|c|c|c|c|c|c|c|c|c|c|c|c|c|}
\hline \multirow{3}{*}{ Body Regions } & \multicolumn{12}{|c|}{ Ectoparasite } \\
\hline & \multicolumn{2}{|c|}{ M.gallinae } & \multicolumn{2}{|c|}{ M. cornutus } & \multicolumn{2}{|c|}{ L. caponis } & \multicolumn{2}{|c|}{ D. gallinae } & \multicolumn{2}{|c|}{ M.ginglymura } & \multicolumn{2}{|c|}{ Haemaphysallis sp. } \\
\hline & $\Sigma$ & $\%$ & $\Sigma$ & $\%$ & $\Sigma$ & $\Sigma$ & $\Sigma$ & $\%$ & $\Sigma$ & $\%$ & $\Sigma$ & $\%$ \\
\hline Head-neck & 142 & 37.9 & 130 & 34.7 & 72 & 19.2 & 31 & 8.3 & - & - & - & \\
\hline Back & 137 & 56.4 & 67 & 27.6 & 16 & 6.6 & 10 & 4.1 & - & - & 2 & 0.8 \\
\hline Wing & - & - & - & - & 26 & 39.4 & - & - & 11 & 4.5 & 40 & 60.6 \\
\hline Breast-foot & 31 & 10.5 & 65 & 22.03 & 54 & 18.3 & 50 & 16.9 & - & - & 36 & 12.2 \\
\hline Tail & - & - & 28 & 29.5 & 16 & 16.8 & - & - & 59 & 20.0 & 33 & 34.7 \\
\hline
\end{tabular}




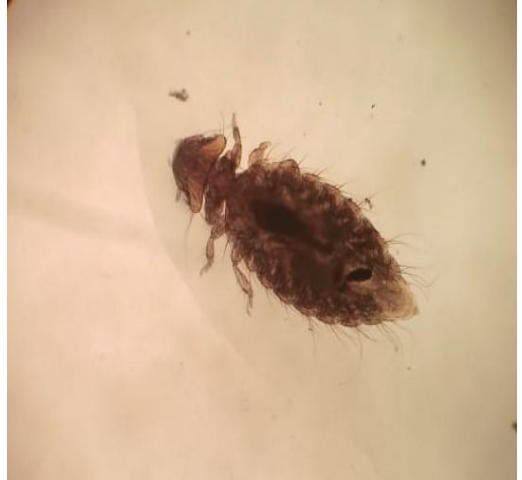

A

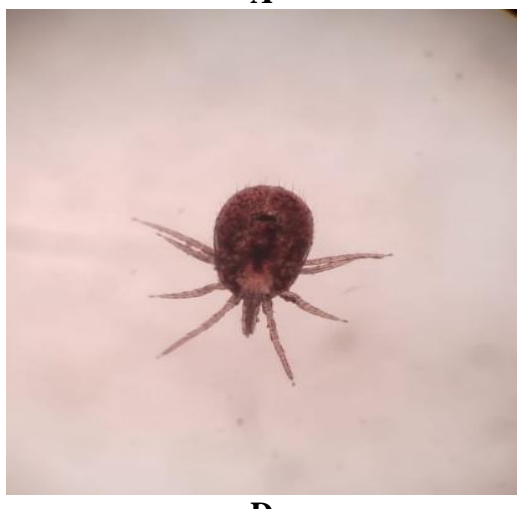

D

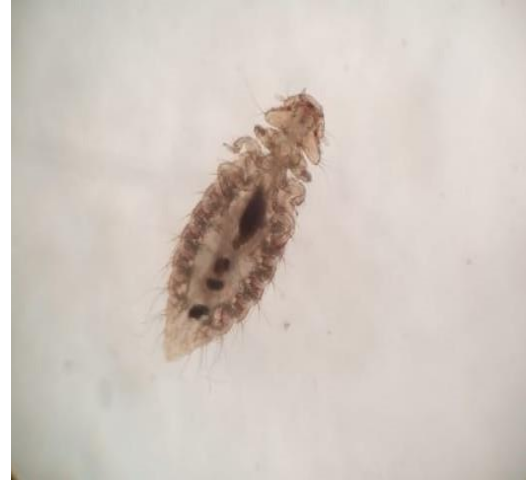

B

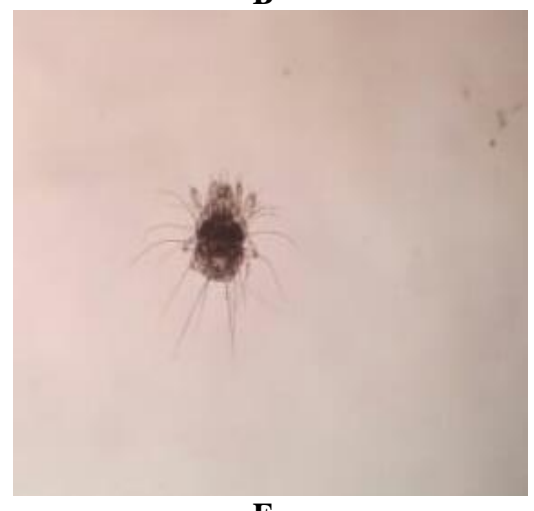

$\mathbf{E}$

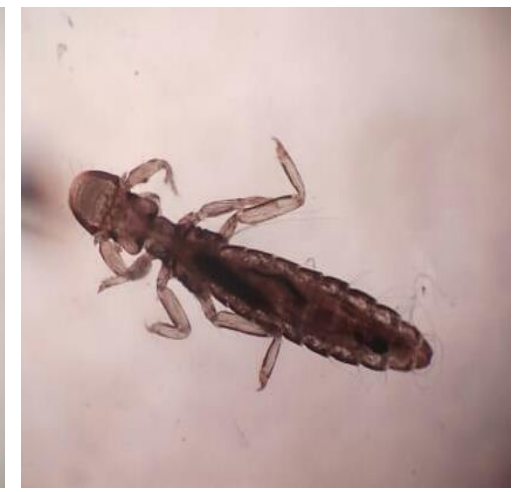

C

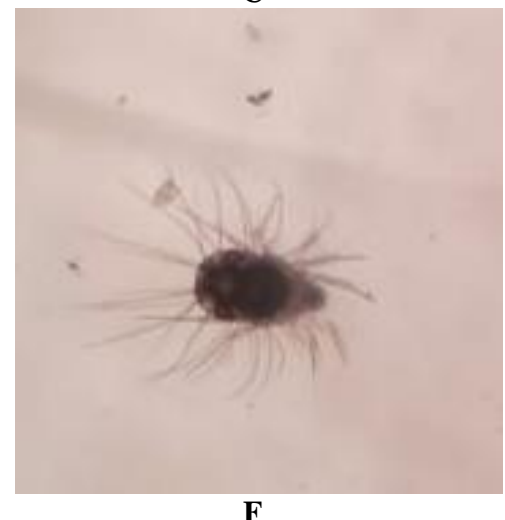

Figure 2. Ectoparasite species found in kampong chickens at five sampling sites. A. Menopon gallinae; B. Menacanthus cornutus; C. Lipeurus caponis; D. Haemaphysallis sp.; E. Dermanyssus gallinae; F. Megninia ginglymura

The results of this study are in line with the majority of studies that found Men. gallinae with the highest prevalence. Suhaila et al. (2015) in North Malaysia found four species of ectoparasites, consisting of three lice and a tick, the highest prevalence being of Men. gallinae (93.8\%), followed by Me. pallidulus (81.3\%), Haemaphysalis sp. (37.5\%), and L. caponis (18.8\%). Furthermore, Men. gallinae was also the most common ectoparasite with $76.7 \%$ occurrence, followed by L. caponis $(63.3 \%$ ) in Penang Malaysia (Rahman and Haziqoh 2015). The same results were found by Ilyes et al. (2013) in their research in Algeria, with the highest prevalence was Men. gallinae (97\%), followed by L. caponis (41\%), and Me.cornutus only 20\%. The dominance of Men. gallinae was also recorded by Deephali et al. (2005) in India, Prelezov and Koinarski (2006) in Bulgaria and Marin-Gomez and Benavides-Montano (2007) in Columbia. In Benin, three species of lice (Men. gallinae, Me. stramineus, and $L$. caponis) were detected and identified on the local poultry. The most abundant species in the study area is Men. gallinae, with a prevalence percentage of about $69.84 \%$ (Love et al. 2017), while Mansur et al. (2019) in Egypt found Men. gallinae to be the most common ectoparasite with $76.7 \%$ occurrence, followed by L. caponis (63.3\%) and $M e$. pallidulus (41.7\%). The difference in this discovery may be due to the difference in environmental factors, especially the daily temperature and humidity (Kaboudi et al. 2019). Overall, the results of this study indicate that the prevalence of ectoparasite in native chicken in Banyumas District is low, compared to the results of research elsewhere. The highest prevalence of $M e$. cornutus only found in the research of Zeryehun and Yohannes (2013) in Ethiopia and Kumar and Kumar (2014) in India.

Table 5. Prevalence of ectoparasite in domestic chicken in five different sampling sites

\begin{tabular}{|c|c|c|c|c|c|c|}
\hline \multirow{2}{*}{ Species } & \multicolumn{5}{|c|}{ Location } & \multirow{2}{*}{$\begin{array}{c}\text { Prevalence }(\%) \\
\text { Means } \pm \text { SD }\end{array}$} \\
\hline & Kedungwuluh & Kedungwringin & Kutasari & Karangaslam & Karanggintung & \\
\hline M. gallinae & 40 & 45 & 40 & 45 & 55 & $45 \pm 5.5$ \\
\hline L.caponis & 45 & 40 & 35 & 35 & 45 & $40 \pm 4.5$ \\
\hline M. cornutus & 35 & 40 & 35 & 35 & 45 & $38 \pm 4.0$ \\
\hline Haemaphysalis sp. & 15 & 20 & 25 & 35 & 35 & $26 \pm 8.0$ \\
\hline D. gallinae & 25 & 10 & 30 & 25 & 35 & $25 \pm 8.4$ \\
\hline M. synglineura & 15 & 15 & 30 & 30 & 35 & $25 \pm 8.4$ \\
\hline
\end{tabular}




\section{Body weight}

In this study, there was a real relationship (r: 0.98) between ectoparasite attacks and weight loss; the higher the ectoparasites attack, the lower the chicken's body weight. This is probably due to irritation for the chickens, thereby reducing sleep and appetite. Ectoparasites of poultry live on the skin or penetrate into the skin or even in the air sacs, while some live under the feathers. The ectoparasites cause irritation, interfere with feed consumption and are thus associated with emaciation, anemia, and eventual loss of production (Mishra et al. 2017). Although poultry lice are not known to transmit any avian pathogens, the presence of lice frequently accompanies poor health attributable to other causes, and is especially harmful to young birds, where large numbers of lice may cause sleep disruption. Amblycera lice may cause irritation to the skin, restlessness, overall weakening, and cessation of feeding. These cause body weight loss, inferior laying capacity, and skin lesions that may become the site for secondary infections (Mullen and Durden 2002). Katoch et al. (2012) reported a $24 \%$ loss in the bodyweight of scavenging chicken in India due to parasitism.

Based on the results of the study, the diversity and prevalence of ectoparasite in native chickens in Banyumas District were classified as low. There we only found six species with the highest prevalence of Men. gallinae at $45 \%$. Ectoparasite infestations in native chickens can cause chicken weight loss. Therefore, even though the prevalence of ectoparasite is low, this is a key area of consideration by the village chicken farmers to prevent ectoparasite attacks on their chicken, hence boosting productivity.

\section{ACKNOWLEDGEMENTS}

We are grateful to Prof. Dr. Suwarto and Prof. Dr. Rifda Naufalin both from University of Jenderal Soedirman Purwokerto, Indonesia, for their support in securing funding for this research, and to all of the students who assisted in collecting field data. This research was supported by funding from the University of Jenderal Soedirman, Purwokerto, Central Java, Indonesia. The authors declare that there are no conflicts of interest regarding the publication of this paper.

\section{REFERENCES}

Aleya B, Sabrina S. 2011. Prevalence and seasonal variation of ectoparasite in pigeon, Columba livia (Gmelin, 1979) of Dhaka, Bangladesh. Bangladesh J Zool 39 (2): 223-230.

El-Aw, MAK, Draz A, Abdel-Hamed A, Awad MA. 2008. Identification of biting lice species on infected domestic chickens and their distribution on different body regions. J Agric Env Sci Alex Univ Egypt 7 (2): 137-143.

Ernieenor FCL, Ernna G, Mariana A. 2017. Phenotypic and genotypic identification of hard ticks of the genus Haemaphysalis (Acari: Ixodidae) in Peninsular Malaysia. Exp Appl Acarol 71: 387-400.

Faleireo DCC, Toldi M, Da Silva GL, Ferla NJ. 2015. The ectoparasites Dermanyssus gallinae and Megninia ginglymura: Bioecology and natural enemies in commercial egg-laying hens. Syst Appl Acarol 20 (8): 861-874. DOI: $10.11158 /$ saa.20.8.3
FAO. 2014. Decision Tools for Family Poultry Development. FAO Animal Production and Health Guidelines, Rome, Italy.

Gunya B, Muhenje V, Gxasheka M, Tyasi LT, Masika PJ. 2020. Management practices and contribution of village chickens to livelihoods of communal farmers: The case of centane and Mount Frere in Eastern Cape, South Africa. Biodiversitas 21 (4): 1345-1351.

Ilyes M, Ahmed B, Kheira S, Hanene D, Fouz M. 2013. Prevalence and distribution of chewing lice (Phthiraptera) in free-range chickens from the traditional rearing system in the Algerian North East, Area of ElTarf. Intl J Poult Sci 12 (12): 721-725.

Kaboudi K, Romdhane RB, Salem AB, Bouzouaia M. 2019. Occurrence of ectoparasites in backyard domestic chickens (Gallus gallus domesticus) in the northeast of Tunisia. J Anim Health Prod 7 (3): 92 98. DOI: 10.17582/journal.jahp/2019/7.3.92.98

Katoch R, Yadav A, Godara R, Khajuria JK, Borkataki S, Sodhi SS. 2012 Prevalence and impact of gastrointestinal helminths on body weight gain in backyard chickens in subtropical and humid zone of Jammu, India. J Parasit Dis 36 (1): 49-52.

Kumar A, Kumar R. 2014. Seasonal changes in the population of Menacanthus cornutus (Phthiraptera: Amblycera). J Parasit Dis 38 (3): 307-310.

Love O, Johnny R, Valentine OR. 2018. A study of the prevalence and abundance of chewing lice (Phthiraptera) in selected poultry farms in Benin City, Edo State. Intl J Anim Sci Tech 1 (1): 35-42.

Mansur KM, Mahmoud NM, Allamoushi SM, El Aziz MM. 2019. Biodiversity and prevalence of chewing lice on local poultry. J Dairy Vet Anim Res 8 (1): 26-31.

Marangi M, Cafiero MA, Capelli G, Camarda A, Sparagano O, Giangaspero A. 2009. Evaluation of the poultry red mite, Dermanyssus gallinae (Acari: Dermanyssidae) susceptibility to some acaricides in field populations from Italy. Exp Appl Acarol 48: 11-18.

Magurran EA. 2000. Ecological Diversity and its Measurement. 2nd ed. Chapman and Hall, London.

Marin-Gomez SY, Benavides-Montano JA. 2007. Parásitos en aves domésticas (Gallus domesticus) en el Noroccidente de Colombia. Vet Zootec 1: 43-51. [Spanish]

McAleece N, Lambshead PJD, Paterson GLJ. 1997. Biodiversity Pro. The Natural History Museum, London.

Mishra S, Pednekar R, Mohanty BS, Gatne M. 2017. Prevalence, economic loss and control of lice infestation in poultry. Intl $\mathbf{J}$ Sci Environ Tech 6 (3): 1745-1757.

Mullen RM, Durden LA 2002. Medical and Veterinary Entomology. $1^{\text {st }}$ ed. Elsevier Science, Nederlands.

Murillo AC, Mullens BA. 2016. Diversity and prevalence of ectoparasites on backyard chicken flocks in California. J Med Entomol 53 (3): 707711.

Nnadi PA, George SO. 2010. A cross-sectional survey on parasites of chickens in selected villages in the subhumid zones of South-Eastern Nigeria. J Parasitol Res. DOI: 10.1155/2010/141824.

Nik-Hassan NRN, Awang A, Rahman AMD. 2015. Parasitic burden and its relation with the bodyweight of free-range chicken in oil palm dominated Sandakan District of Malaysian Borneo. Intl J Livestock Res. DOI: 10.5455/ijlr.20150909073638.

Oliveira TM, Teixeira CM, Arcebispo TCM, Antunes KD, Rezende LC, Cunha LM, Diniz TA, Silva MX. 2017. Epidemiological characterization and risk evaluation associated with the presence of Megninia spp. in posture farms. Ciência Rural, Santa Maria, v.47: 09, e20170186

Prelezov PN, Koinarski KV. 2006. Species variety and population structure of Mallophaga (Insecta: Phthiraptera) on chickens in the region of Stara Zagora. Bulgarian J Vet Med 9 (3): 193-200.

Rahman WA, Haziqoh F. 2015. Ectoparasitic fauna of scavenging chickens (Gallus domesticus) from Penang Island, Peninsular Malaysia. Malaysian J Vet Res 6 (1): 33-42

Sparagano O, Pavlicevic A, Murano T, Camarda A, Sahibi H, Kilpinen O, Mul M, Emous RV, Bouquin S, Hoel K, Cawero MA. 2009. Prevalence and key figures for the poultry red mite Dermanyssus gallinae infections in poultry farm systems. Exp Appl Acarol 48: 310 .

Suhaila AH, Sabrina DL, Ahmad N, Irwan Izzauddin NH, Hamdan A, Khadijah S. 2015. Study of parasites in commercial free-range chickens in northern Peninsular Malaysia. Malaysian J Vet Res 6: 5364 
Sreedevi C, Ramesh P, Mala Kondaiah P, Lakshmi Rani N, \& Abhishek M. 2016. Occurrence of Knemidokoptes mutans and Laminosioptes crysticola in backyard poultry in India. J Parasitic Dis 40: 1627-1630.

Swai ES, Kessy M, Sanka P, Bwanga S, Kaaya JE. 2010. A survey on ectoparasites and haemoparasites of free-range indigenous chickens of Northern Tanzania. Livest Res Rural Dev 22 (9).
Zeryehun T, Yohannes Y, 2015. Ectoparasite infestation of free scavenging chickens reared under traditional backyard production system in Wolayita Zone, Southern Ethiopia. Ethiopian Vet J 19 (2): 55-66. 